\section{Disseminated Cryptococcal Infection and Anti-Tumor Necrosis Factor- $\alpha$ Treatment for Refractory Sarcoidosis: An Expected Association?}

\section{To the Editor:}

The use of anti-tumor necrosis factor- $\alpha$ (anti-TNF- $\alpha$ ) agents is validated in refractory rheumatoid arthritis, psoriatic arthritis, ankylosing spondylitis, Crohn's disease, and ulcerative colitis. Although very effective in breaking down granulomatous inflammation typically involved in sarcoidosis, antiTNF- $\alpha$ agents significantly reduce the host granulomatous defence mechanisms that normally contain pathogens such as mycobacteria and fungi. We describe a case of disseminated cryptococcosis in a patient with refractory systemic sarcoidosis, in whom complete resolution followed discontinuation of anti-TNF- $\alpha$ drug and antifungal therapy.

A 42-year-old man was referred to our internal medicine department with a 2-year history of unexplained left-ear deafness and lymphocytic meningitis. Clinical examination was normal except for left-ear deafness. Gadolinium-enhanced magnetic resonance imaging (MRI) showed multiple solid enhancing lesions involving the left internal acoustic canal and the left frontal lobe. Cerebrospinal fluid (CSF) analysis revealed lymphocytosis $\left(85 / \mathrm{mm}^{3}\right)$, elevated CSF protein $(1.24 \mathrm{~g} / \mathrm{l})$, and low glucose CSF concentrations $(1.4 \mathrm{mmol} / \mathrm{l})$. Viral, bacterial, and fungal cultures were negative. Thoracic computed tomography (CT) scan showed multiple bilateral hilar and mediastinal lymphadenopathies, with no parenchymal involvement. PPD tuberculosis skin test (10 IU) was positive $(7 \mathrm{~mm})$. Serum angiotensin-converting enzyme level was normal and HIV test was negative. The bronchoalveolar lavage interpretation formula and CD4/CD8 ratio were suggestive of sarcoidosis. Histopathological examination of multiple bronchial biopsies revealed noncaseating epithelioid granulomas with a few giant cells. No acid-fast bacilli were identified and cultures were negative.

Treatment with prednisone was initiated at $60 \mathrm{mg} / \mathrm{day}$, then tapered to $35 \mathrm{mg} /$ day over 11 months. At this time, the patient complained of headaches. Clinical examination showed severe bilateral visual acuity loss. Ophthalmologic examination revealed a bilateral papillary edema. MRI showed a triventricular hydrocephaly and disappearance of the solid lesions. CSF analysis was unchanged. An empirical 3-month course of antituberculosis treatment was not successful, and he required insertion of a ventriculo-peritoneal shunt. A thallium myocardial scintigraphy scan revealed an inflammatory myocardial involvement, while cardiac MRI was normal. Monthly intravenous pulses of cyclophosphamide were initiated. Thirteen months later, thallium myocardial scintigraphy result was normal. Because CSF analysis remained unchanged, cyclophosphamide was discontinued, and he was treated with thalidomide and clarithromycin, followed by intramuscular methotrexate $(25 \mathrm{mg} / \mathrm{week})$. One year later, thallium myocardial scintigraphy and myocardial MRI showed reappearance of myocardial involvement. Etanercept ( $25 \mathrm{mg}$ twice a week) was added to the previous regimen, and then switched to infliximab $(5 \mathrm{mg} / \mathrm{kg}$ ) after 11 months, as myocardial scintigraphy, MRI, and CSF analysis were still unimproved. Three days after the second infliximab infusion, he complained of high fever and cough. Clinical examination and thorax CT scan were normal. He was given an empirical treatment with amoxicillin and roxithromycin. Ten days later, 2 positive fungal blood cultures indicated presence of Cryptococcus neoformans. Unexpectedly, the CSF finding was markedly improved (13 cells $/ \mathrm{mm}^{3}$, lymphocytes 53\%). Gram and India ink staining, cryptococcal antigen test, and standard and fungal cultures of CSF were all negative. Immunosuppressive treatments were discontinued, and a combination therapy of amphotericin $(0.7 \mathrm{mg} / \mathrm{kg} / \mathrm{day})$ and flucytosine $(100$ $\mathrm{mg} / \mathrm{kg} /$ day) was successfully initiated. Based on antifungigram results, fluconazole $(200 \mathrm{mg} /$ day $)$ was used as maintenance therapy. At 12-month followup, the patient remained asymptomatic taking fluconazole (200 $\mathrm{mg} / \mathrm{day})$ and prednisone (15 mg/day). The myocardial scintigraphy scan remained normal; the cardiac MRI still highlighted stable apical enhancement.

Sarcoidosis is a multisystemic inflammatory disorder characterized by presence of noncaseating epithelioid granulomas that may affect any organ. Steroids are the mainstay of treatment, but refractory cases or life-threatening localization of the disease may require more aggressive treatment with other immunosuppressive agents such as anti-TNF- $\alpha$ agents. Although our patient was asymptomatic, thallium myocardial scintigraphy indicated inflammatory cardiac involvement. Chapelon-Abric, et al ${ }^{1}$ showed that cardiac sarcoidosis is clinically asymptomatic in $41 \%$ of cases, and that diagnosis of cardiac sarcoidosis must be based on morphological (echography), functional (radionuclide imaging), and/or electrocardiographic abnormalities. In our patient, cardiac and neurological involvements were refractory to conventional treatments, which prompted us to use anti-TNF- $\alpha$ agents, with no clear success.

Only a few cases of concurrent cryptococcal infections and sarcoidosis have been reported ${ }^{2-4}$, while a significant number of cases of cryptococcosis occurring under anti-TNF- $\alpha$ therapies have been reported in patients with rheumatoid arthritis ${ }^{5-8}$. The increased occurrence of cryptococcal infections during anti-TNF- $\alpha$ therapies may be explained by the critical role of TNF- $\alpha$ in development of a protective T cell-mediated immunity to C. neoformans ${ }^{9}$. Therefore, patients with sarcoidosis treated by anti-TNF$\alpha$ therapy accumulate 2 major risks of developing cryptococcal infection - the cellular defect due to the underlying disease and the blockade of TNF- $\alpha$, known to be critical in protection against intracellular organisms. Hence, the use of anti-TNF- $\alpha$ drugs in refractory sarcoidosis should be associated with careful followup and a systematic search for a cryptococcal infection in the presence of any potentially related manifestation.

\section{LAURENT ARNAUD, MD; DAMIEN SENE, MD; NATHALIE} COSTEDOAT-CHALUMEAU, MD, PhD; PATRICE CACOUB, MD CATHERINE CHAPELON-ABRIC, MD; JEAN-CHARLES PIETTE, MD, Service de Médecine Interne, Hôpital Pitié-Salpêtrière, 47-83 Boulevard de l'Hôpital, 75013 Paris, France. Address reprint requests to Dr Sène; E-mail: damien.sene@psl.aphp.fr

\section{REFERENCES}

1. Chapelon-Abric C, de Zuttere D, Duhaut P, et al. Cardiac sarcoidosis: a retrospective study of 41 cases. Medicine Baltimore 2004;83:315-34.

2. Heller S, McLean RA, Campbell CG, Jones IH. A case of coexistent nonmeningitic cryptococcosis and Boeck's sarcoid. Am J Med 1957;22:986-94

3. Gibold X, Husson A, Corbain V, et al. Cryptococcal meningitis disclosed by visual loss in HIV negative patient with ventriculo-atrial shunting [French]. Rev Med Interne 2006;27:330-2.

4. Ross JJ, Katz JD. Cryptococcal meningitis and sarcoidosis. Scand J Infect Dis 2002;34:937-9.

5. Shrestha RK, Stoller JK, Honari G, Procop GW, Gordon SM. Pneumonia due to Cryptococcus neoformans in a patient receiving infliximab: possible zoonotic transmission from a pet cockatiel. Respir Care 2004;49:606-8.

6. Hage CA, Wood KL, Winer-Muram HT, Wilson SJ, Sarosi G, Knox KS. Pulmonary cryptococcosis after initiation of anti-tumor necrosis factor-alpha therapy. Chest 2003;124:2395-7.

7. Arend SM, Kuijper EJ, Allaart CF, Muller WH, Van Dissel JT. Cavitating pneumonia after treatment with infliximab and prednisone. Eur J Clin Microbiol Infect Dis 2004;23:638-41.

8. True DG, Penmetcha M, Peckham SJ. Disseminated cryptococcal infection in rheumatoid arthritis treated with methotrexate and infliximab. J Rheumatol 2002;29:1561-3.

9. Kawakami K, Qifeng X, Tohyama M, Qureshi MH, Saito A. Contribution of tumour necrosis factor-alpha (TNF-alpha) in host defence mechanism against Cryptococcus neoformans. Clin Exp Immunol 1996;106:468-74.

J Rheumatol 2009;36:2; doi 103899/jrheum.080426 Personal non-commercial use only. The Journal of Rheumatology Copyright @ 2009 . All rights reserved. 